Arq. Bras. Med. Vet. Zootec., v.68, n.2, p.271-275, 2016

\title{
Intra-uterine exposure of horses to Sarcocystis spp. antigens
}

\author{
[Exposição intrauterina ao Sarcocystis spp. em equinos] \\ A.M. Antonello ${ }^{1}$, G.C. Cadore ${ }^{1}$, F.L. Pivoto ${ }^{1}$, G. Camillo $^{1}$, P. Braunig ${ }^{1}$, L.A. Sangioni ${ }^{1}$, \\ E. Pompermayer ${ }^{2}$, L.F.P. Gondim ${ }^{3}$, F.S.F. Vogel ${ }^{1 *}$ \\ ${ }^{1}$ Universidade Federal de Santa Maria -Santa Maria, RS \\ ${ }^{2}$ Equine Hospital, Qatar Racing \& Equestrian Club - Doha, Qatar 7559. \\ ${ }^{3}$ Universidade Federal da Bahia - Salvador, BA
}

\begin{abstract}
The aim of this study was to examine the intra-uterine exposure to Sarcocystis spp. antigens, determining the number of foals with detectable concentrations of antibodies against these agents in the serum, before colostrum ingestion and collect data about exposure of horses to the parasite. Serum samples were collected from 195 thoroughbred mares and their newborns in two farms from southern Brazil. Parasite specific antibody responses to Sarcocystis antigens were detected using the indirect immunofluorescent antibody test (IFAT) and immunoblot analysis. In $84.1 \%(159 / 189)$ of the pregnant mares and in $7.4 \%$ $(14 / 189)$ of foals we detected antibodies anti-Sarcocystis spp. by IFAT. All samples seropositive from foals were also positive in their respective mares. Serum samples of seropositive foals by IFAT, showed no reactivity on the immunoblot, having as antigens $S$. neurona merozoites. In conclusion, the intrauterine exposure to Sarcocystis spp. antigens in horses was demonstrated, with occurrence not only in mares, but also in their foals, before colostrum ingestion these occurrences were reduced.
\end{abstract}

Keywords: equine protozoal mieloencephalitis, transplacental infection, seroprevalence, indirect fluorescent antibody test, immunoblot

\section{RESUMO}

O objetivo deste estudo foi avaliar a exposição intrauterina ao Sarcocystis spp., para determinar o número de potros que possuem concentrações detectáveis de anticorpos contra esses agentes no soro, antes da ingestão do colostro, por meio da coleta de dados sobre a exposição a esses protozoários nos equinos. Amostras de soro foram coletadas de 195 éguas puro-sangue e seus respectivos potros recémnascidos, em duas fazendas localizadas na região Sul do Brasil. Os testes utilizados na detecção de anticorpos específicos para o Sarcocystis foram a reação de imunofluorescência indireta (RIFI) e análise por meio de immunoblot. Pela RIFI, em 84,1\% (159/189) das éguas e em 7,4\% (14/189) dos potros foram detectados anticorpos anti-Sarcocystis spp. Todas as amostras soropositivas dos potros também foram positivas para suas respectivas mães. As amostras de soro dos potros soropositivos na RIFI, não apresentaram reatividade no immunoblot, tendo como antígenos merozoítos de $\mathrm{S}$. neurona. Em conclusão, foi demonstrada a exposição intrauterina de Sarcocystis spp. em equinos, com ocorrência em éguas, porém, em seus respectivos potros, antes da ingestão de colostro a ocorrência foi reduzida.

Palavras-chave: mieloencefalite protozoária equina, infecção transplacentária, soroprevalência, reação de imunofluorescência indireta, immunoblot

\section{INTRODUCTION}

The genus Sarcocystis has more than 100 species that infect various animal species, requiring an intermediate and a definitive host to complete the

Recebido em 1 de abril de 2014

Aceito em 15 de novembro de 2015

* Autor para correspondência (corresponding author)

E-mail: fefevogel@gmail.com life cycle and the sarcocystosis is one of the most prevalent parasitic diseases in animals with worldwide distribution (Tenter, 1995). Canids and opossum (Didelphis sp.) are definitive hosts of the Sarcocystis cruzi (Dubey and Lindsay, 2006) and the Sarcocystis neurona (Fenger et al., 
1995; Dubey et al, 2001) respectively, and horses can be their intermediate hosts (Dubey et al, 2001). Transplacental transmission by Apicomplexa protozoa belonging to species of Sarcocystis, Neospora and Toxoplasma are related in animals of different species (Dubey, 1994; Tenter, 1995; Dubey, 2003). In horses, Neospora spp. and T. gondii have been detected in fetuses, newborn and foals, indicating that vertical transmission of the parasites may occur (Turner and Savva, 1990; Lindsay et al., 1996).

The $S$. neurona is described as the main agent of equine protozoal myeloencephalitis (EPM), a progressively debilitating neurological disease, which is often fatal (Dubey et al., 2001). The $N$. hughesi is also associated with EPM, causing similar clinical signs and microscopic lesions as S. neurona (Marsh et al., 1996). The diagnosis of EPM is usually based on results of clinical examination and by detection of the presence of Sarcocystis spp. specific antibodies in serum and cerebrospinal fluid (CSF) evaluation by immunoblot test (Granstrom et al., 1993).

The S. neurona is phylogenetically closely related to other cyst-forming protozoa that showed vertical transmission and some studies suggest its endogenous pathway transmission in horses. Evaluation of results of serological tests in young horses for the presence of Sarcocystis spp. antibodies may be complicated by the possibility of in utero exposure and the passive transfer of specific maternal antibodies (Cook et al., 2001). Detection of antibodies against $S$. neurona in pre-colostrum newborn serum indicates that the foal was exposed to parasite antigens in intra-uterine life, by the trans placental route (Perryman et al., 1980; AbdElnaeim et al., 2006). Therefore, the aim of this study was to examine the intra-uterine exposure to Sarcocystis spp. antigens, determining the number of foals that have detectable antibody dilution against these agents in the serum, before colostrum ingestion, and collect data about exposure of horses to the parasite in Brazil.

\section{MATERIAL AND METHODS}

Serum samples were collected from 195 thoroughbred mares and their newborns in two farms from Southern Brazil. The animals were routinely monitored by a veterinarian and all deliveries were attended. Blood samples were collected immediately after delivery from mares and before colostrum ingestion from newborns. After collection, whole blood was centrifuged at $250 \mathrm{xg}$ for 10 minutes at room temperature to obtain the serum, which was stored at $-20^{\circ} \mathrm{C}$ until testing.

The survey of immunoglobulin G (IgG) anti-S. neurona was performed using indirect fluorescent antibody test (IFAT). S. neurona merozoites of SN-37R strain (Sofaly et al., 2002) were used as antigen. To carry on IFAT with the mares' serum samples, we used a cutoff of 1:50 for screening, whereas the foals were considered positive at a dilution of 1:25. Anti-equine IgG (Goat Anti-Equine IgG FITC ${ }^{\circledR}$, 160A, Southern Biotech, Oxmoor Blvd, Birmingham, USA) antibody conjugated to fluorescein was used as the secondary antibody. Serum samples known to be positive (from a mare experimentally infected, that was seronegative for Neospora spp.) or negative (from a seronegative newborn) for the presence of antibodies against $S$. neurona were used as positive and negative controls, respectively, on each slide. Samples were considered positive if there was fluorescence on the entire $S$. neurona merozoites surface, and as negative when the fluorescence was either apical or absent (Duarte et al., 2003). After obtaining the positive and negative results from IFAT, samples from positive mares were titrated. Titers were determined by the maximum dilution at which the fluorescence was observed.

The immunobloting was performed according to Granstrom et al. (1993), with modifications in foals' positive serum samples for Sarcocystis spp. Immunoblots were prepared with $S$. neurona antigens by using a concentration of $10^{7}$ parasites $/ \mathrm{mL}$ sonicated four times, $15 \mathrm{~s}$ each at $40 \mathrm{MHz}$. Buffer was added and samples were heated at $95^{\circ} \mathrm{C}$ for $5 \mathrm{~min}$ and the proteins were separated electrophoretically on a $15 \%$ sodium dodecyl sulfate-polyacrylamida gel electrophoresis (SDS-PAGE) at $120 \mathrm{~V}$ and $10 \mathrm{~mA}$ by $120 \mathrm{~min}$. Pre stained SDS-PAGE molecular weight markers (High-and low-range SDSPAGE molecular weight markers, Bio-Rad Laboratories) were included with each gel. After separation by electrophoresis, antigens were then transferred to Nitrocellulose Supported Transfer Membrane $\left(\mathrm{Gibco}^{\circledR}\right)$. Before applying the primary antibody, membranes were blocked with $5 \%(\mathrm{w} / \mathrm{v})$ dried milk in tris-buffered saline plus 
tween (TBS-t) solution. Membranes were allocated in mini blotter, with each lane probed with equine serum samples at dilution 1:10 (Vardeleon et al., 2001). Serum from a horse infected with $S$. neurona was included as positive control for immunoblot, and a negative control horse were included as well. These were incubated overnight at $4^{\circ} \mathrm{C}$ and membranes were then washed three times for $10 \mathrm{~min}$ each with TBS-t and incubated with a secondary antibody, peroxidase labeled rabbit anti-equine IgG (AntiHorse IgG - Peroxidase, Sigma-Aldrich, St. Louis, MO) for $1 \mathrm{~h}$ at room temperature followed by washing and development using 3,3'diaminobenzidine (Sigma-Aldrich, St. Louis, MO).

The serological prevalence of mares and precolostral foals, as well as the frequency of vertical transmission were compared using chisquare contingency tables. $P$ values to assess the statistical difference were calculated by Fisher's test (GraphPad Prism $5^{\circledR}$ ).

All procedures of animal handling and experimentation were performed according to recommendations from the Brazilian Committee and Experimentation (Cobea; law \# 6.638 of May 8, 1979) and were approved by the Animal Use Ethics Committee (CEUA) of Universidade Federal de Santa Maria, registration number 081/2009.

\section{RESULTS AND DISCUSSION}

The genus Sarcocystis host range is large, making it difficult to control in the herds. To investigate the occurrence of transplacental transmission, the presence of immunoglobulins in mare serum during parturition and in their newborns before colostrum ingestion was evaluated. To determine the vertical transmission occurrence by genus Sarcocystis in horses, antibodies anti-Sarcocystis spp. was researched in serum from mares and their foals by IFAT. Screening of pregnant mares revealed that $84.1 \%$ $(159 / 189)$ were seropositive for Sarcocystis spp., and $7.4 \%(14 / 189)$ of foals were positive for antibodies to Sarcocystis spp. A high occurrence among mares was observed when compared with other studies (Dubey et al., 1999; Hoane et al., 2006), considering that the prevalence varies according to the region and group of animals evaluated (Vardeleon et al., 2001). The lower antibodies against Sarcocystis spp. detected in foals $(7.4 \%$ - 14/189) was expected, because the neonatal foals before suckling are a gamma globulinemics, due to the equine placenta being characterized as a difuse, epitheliochorial type which prevents any significant placental transmission of antibodies during gestation (Jeffcott, 1974; Jeffcott, 1975).

No reports were found regarding intrauterine exposure to Sarcocystis in spite of its phylogenetic proximity with other protozoa of which transplacental infection has been confirmed as Neospora spp. (Locatelli-Dittrich et al., 2006; Pusterla et al., 2010; Antonello et al., 2012) and T. gondii (Williams et al., 2005). However, there is evidence that as other apicomplexas, the Sarcocystis can also establish endogenous infection. As the report of a foal whose mother was seropositive for $S$. neurona at two days of age, the foal showed signs of EPM and at two months old the cerebrospinal fluid was positive in the westernblot test (Gray et al., 2001). Since the seroconversion occurs at about 30 days after infection (Cutler et al., 2001), it is suggestive that this foal was infected with $S$. neurona in the uterus. Other evidence that supports the hypothesis of vertical transmission by this protozoan is the occurrence of seropositive horses in areas where the definitive host of S. neurona is absent (Pitel et al., 2002) found in seropositive animals born in France that never left the country and had no contact with Didelphis spp.

To detect vertical transmission, serum samples were collected from newborn foals. To minimize these biases, serum samples from neonatal foals were collected before ingestion of colostrum. In this study, 14 foals had low IFAT titers (antibody level of 25) to Sarcocystis spp. and these titers were lower than the cutoffs considered indicative of infection, with all samples positive from foals being also positive in mares. Lower cutoff values were used to enhance test sensitivity for exposure screening to the parasite. Fetal horse is able to form a humoral immune response around 180 days of gestation (Perryman et al., 1980), thus antibodies will be present in pre-colostral newborn serum if it is exposed to protozoan thereafter. Statistical analysis of these data demonstrate that there was no difference in likelihood of transplacental infection when the evaluated variable is the titer of maternal 
antibodies. This way, it can be stated that the antibody detected in newborns' serum without passive immunity ingestion by colostrum could be the intrauterine infection occurrence and the development of adaptive immunity for infants. Therefore, in this study the foals that were seropositive and that were born of seropositive mares may indicate that vertical transmission may be occurring among the studied horses.

Serological tests can generate false results due to cross-reaction with associated parasites, but this risk was decreased by the methodology used. No positive foal samples by IFAT were positive for immunoblotting, indicating that animals were not infected with $S$. neurona. The IFAT has specificity and sensibility similar to immunoblot, the gold standard test for S. neurona. Moreover, despite genera belonging to the same phylum sharing some surface antigens, a result is positive only if the entire Sarcocystis merozoites surface was fluorescent (Duarte et al., 2003). The immunoblot test detects the presence of $S$. neurona specific antibodies in serum and cerebrospinal fluid, with sensitivity and specificity to nearly $100 \%$ based on the elimination of cross-reactivity with $S$. cruzi (Granstrom et al., 1993; Rossano et al., 2000).

\section{CONCLUSION}

This study demonstrated the intra-uterine exposure to Sarcocystis antigens in horses, showing an occurrence of antibodies against Sarcocystis spp. not only in mares, but in their foals. Before colostrum ingestion these occurrences were reduced.

\section{ACKNOWLEDGMENT}

The authors would like to thank the BioRep and Virology from UFSM, for the availability of equipment and veterinary practitioners Paulo $\mathrm{N}$. L. Bergamo, Friedrich Frey Jr. and Sabine Kasinger for their cooperation. We also thank CNPq, CAPES and FAPERGS for the financial support with the materials and equipment needed.

\section{REFERENCES}

ABD-ELNAEIM, M.M.M.; LEISER, R.; WILSHER, S.; ALLEN, W.R. Structural and haemovascular aspects of placental growth throughout gestation in young and aged mares. Placenta, v.27, p.1103-1113, 2006.

ANTONELLO, A.M.; PIVOTO, F.L.; CAMILLO, G. et al. The importance of vertical transmission of Neospora sp. in naturally infected horses. Vet. Parasitol., v.187, p.367370, 2012.

COOK, A.G.; BUECHNER-MAXWELL, V.; MORROW, J.K. et al. Interpretation of the detection of Sarcocystis neurona antibodies in the serum of young horses. Vet. Parasitol., v.95, p.187-195, 2001.

CUTLER, T.J.; MACKAY, R.J.; GINN, P.E. et al. Immuno conversion against Sarcocystis neurona in normal and dexamethasone-treated horses challenged with S. neurona sporocysts. Vet. Parasitol., v.95, p.197-210, 2001.

DUARTE, P.C.; DAFT, B.M.; CONRAD, P.A. et al. Comparison of a serum indirect fluorescent antibody test with two western blot tests for the diagnosis of equine protozoal myeloencephalitis. J. Vet. Diagn. Invest., v.15, p.8-13, 2003.

DUBEY, J.P. Review of Neospora caninum and neosporosis in animals. Korean J. Parasitol., v.41, p.1-16, 2003.

DUBEY, J.P. Toxoplasmosis. J. Am. Vet. Med. Assoc., v.205, p.1593-1598, 1994.

DUBEY, J.P.; LINDSAY, D.S.; SAVILLE, W.J. et al. A review of Sarcocystis neurona and equine protozoal myeloencephalitis (EPM). Vet. Parasitol., v.95, p.89-131, 2001.

DUBEY, J.P.; LINDSAY, D.S. Neosporosis, toxoplasmosis, and sarcocystosis in ruminants. Vet. Clin. Food. Anim. v.22, p.22:645-671, 2006.

DUBEY, J.P.; VENTURINI, M.C.; VENTURINI, L. et al. Prevalence of antibodies to Sarcocystis neurona, Toxoplasma gondii and Neospora caninum in horses from Argentina. Vet. Parasitol., v.86, p.59-62, 1999.

FENGER， C.K.; GRANSTROM， D.E.; LANGEMEIER, J.L. et al. Identification of opossums (Didelphis virginiana) as the putative definitive host of Sarcocystis neurona. $J$. Parasitol., v.81, p.916-919, 1995. 
GRANSTROM, D.E.; DUBEY, J.P.; DAVIS, S.W. et al. Equine protozoal myeloencephalitis: antigen analysis of cultured Sarcocystis neurona merozoites. J. Vet. Diagn. Invest., v.5, p.88-90, 1993.

GRAY, L.C.; MAGDESIAN, K.G.; STURGES, B.K.; MADIGAN, J.E. Suspected protozoal myeloencephalitis in a two-month-old colt. Vet. Rec., v.149, p.269-273, 2001.

HOANE, J.S.; GENNARI, S.M.; DUBEY, J.P. et al. Prevalence of Sarcocystis neurona and Neospora spp. infection in horses from Brazil based on presence of serum antibodies to parasite surface antigen. Vet. Parasitol., v.136, p.155159, 2006.

JEFFCOTT, L.B. Some practical aspects of the transfer of passive immunity to newborn foals. Equine Vet. J., v.6, p.109-115, 1974.

JEFFCOTT, L.B. The transfer of passive immunity to the foal and its relation to immune status after birth. J. Reprod. Fert. Suppl., v.23, p.727-733, 1975.

LINDSAY, D.S.; STEINBERG, H.; DUBIELZIG, R.R. et al. Central nervous system neosporosis in a foal. J. Vet. Diag. Invest., v.8, p.507-510, 1996.

LOCATELLI-DITTRICH, R.; DITTRICH, J.R.; RICHARTZ, R.R.T.B. et al. Investigation of Neospora sp. and Toxoplasma gondii antibodies in mares and in precolostral foals from Parana State, Southern Brazil. Vet. Parasitol., v.135, p.215-221, 2006.

MARSH, A.E.; BARR, B.C.; MADIGAN, J. et al. Sequence analysis and polymerase chain reaction amplification of small subunit ribosomal DNA from Sarcocystis neurona. Am. J. Vet. Res., v.57, p.975-981, 1996.

PERRYMAN, L.E.; MCGUIRE, T.C.; TORBECK, R.L. et al. Ontogeny of lymphocyte function in the equine fetus. Am. J. Vet. Res., v.41, p.1197-1200, 1980.
PITEL, P.H.; PRONOST, S.; GARGALA, G. et al. Detection of Sarcocystis neurona antibodies in French horses with neurological signs. Int. J. Parasitol., v.32, p.481-485, 2002.

PUSTERLA, N.; CONRAD, P.A.; PACKHAM, A.E. et al. Endogenous transplacental transmission of Neospora hughesi in naturally infected horses. J. Parasitol., v.97, p.281-285, 2010.

ROSSANO, M.G.; MANSFIELD, L.S.; KANEENE, J.B. et al. Improvement of western blot test specificity for detecting equine serum antibodies to Sarcocystis neurona. J. Vet. Diagn. Invest., v.12, p. 28-32, 2000.

SOFALY, C.D.; REED, S.M.; GORDON, J.C. et al. Experimental induction of equine protozoan myeloencephalitis (EPM) in the horse: effect of Sarcocystis neurona sporocyst inoculation dose on the development of clinical neurologic disease. J. Parasitol., v.88, p.1164-1170, 2002.

TENTER, A.M. Current research on Sarcocystis species of domestic animals. Int. J. Parasitol., v.25, p.1311-1330, 1995.

TURNER, C.B.; SAVVA, D. Evidence of Toxoplasma gondii in an equine placenta. Vet. Rec., v.127, p.96, 1990.

VARDELEON, D.; MARSH, A.E.; THORNE, J.G. et al. Prevalence of Neospora hughesi and Sarcocystis neurona antibodies in horses from various geographical locations. Vet. Parasitol., v.95, p.273-282, 2001.

WILLIAMS, R.H.; MORLEY, E.K.; HUGHES, J.M. et al. High levels of congenital transmission of Toxoplasma gondii in longitudinal and crosssectional studies on sheep farms provides evidence of vertical transmission in ovine hosts. Parasitology, v.130, p.301-307, 2005. 